\title{
A NEW AND STRIKING SPATHOGLOTTIS (ORCHIDACEAE: COLLABIINAE), HONORING HER MAJESTY THE QUEEN OF BHUTAN
}

\author{
Nima Gyeltshen ${ }^{1}$, Kezang Tobgyel $^{1} \&$ Stig Dalström $^{1,2,3}$ \\ ${ }^{1}$ National Biodiversity Centre, Serbithang, Thimphu, Bhutan \\ 222304 Ringling Boulevard, unit 119, Sarasota FL 34237, U.S.A. \\ Lankester Botanical Garden, University of Costa Rica, Cartago, Costa Rica \\ ${ }^{3}$ Corresponding author: stigdalstrom@gmail.com
}

\begin{abstract}
AвSTRACT. A new, attractive and morphologically unique species of Spathoglottis is described, illustrated and compared with the most similar species. The new species is currently only known from two localities in southeastern Bhutan and differs distinctly from its closest relative, Spathoglottis hardingiana, by the glabrous pedicels, forward-curved acuminate apices of the petals, a yellow hypochile of the lip, two pairs of unequal callus "horns" and swellings, and a spirally coiled epichile of the lip, versus a densely pubescent inflorescence and pedicels, a pale purple hypochile, a single pair of erect and clavate, or"bubble-shaped", callus swellings, and a projecting and narrowly triangular epichile of the lip for S. hardingiana.
\end{abstract}

KeY words: Orchidaceae, Collabiinae, new species, Spathoglottis, Bhutan

Introduction. The genus Spathoglottis Blume was described in 1825 in Bijdragen tot de Flora van Nederlandsch Indië (Blume 1825-1827). The genus currently consists of approximately 50 species (Govaerts 2017) with some additional varieties and natural hybrids, distributed in India, Nepal, Bhutan, throughout subtropical SE Asia, China, Indonesia, New Guinea, Australia and the Pacific Islands.

On November 3, 2016, the remote region of Ngangla-Kaktong in the Zhemgang district of Bhutan (Fig. 1) was explored by National Biodiversity Centre's (NBC) Biodiversity Researchers Nima Gyeltshen and Kezang Tobgyel, and former contract staff Tandin Wangchuk, currently a Forest Ranger I in Trashigang Forest Division. The objective was to collect seeds for the Tree Seed Conservation Project.

The chosen location is also known to support small populations of Paphiopedilum fairrieanum (Lindl.) Stein (Fig. 2A, and P. venustum (Wall. ex Sims) Pfitzer (Fig. 2B). These orchid species are considered critically endangered throughout their known distribution in the Himalayan tropical to subtropical region but fortuitously grow together in limestone areas in the Ngangla-Kaktong area.

During the 2016 trip, it was observed that, although small and vulnerable, populations of Paphiopedilum fairrieanum (Lindl.) Stein and P. venustum (Wall. ex Sims) were still present and appearing healthy. The NBC team therefore decided to make a survey to document the species composition with a total of three plots where Paphiopedilum plants were present, with an area of $10 \times 10 \mathrm{~m} 2$ for tree vegetation and 2 x $2 \mathrm{~m} 2$ for the ground vegetation (Fig. 3). During the composition survey of ground vegetation, a striking terrestrial orchid in full bloom was discovered inside the selected plot, which was at 1038 m.a.s.l. elevation. After returning to the base camp the specimen was processed and scanned and tentatively identified as an unusual Spathoglottis species. Later, photos were sent for a positive identification to Dhan Bdr. Gurung (College of Natural Resources, Lobesa, Bhutan), and Stig Dalström who confirmed that the attractive flowers indeed belong to a new and striking Spathoglottis species (Fig. 4-6).

Later, on November 8, 2016, the same NBC team made a trip to the remote villages of Martshala and Sarjung in the Samdrup Jongkhar district for additional tree seed collection and pre-collection assessments. Amazingly, another observation of the new Spathoglottis species was made growing on 


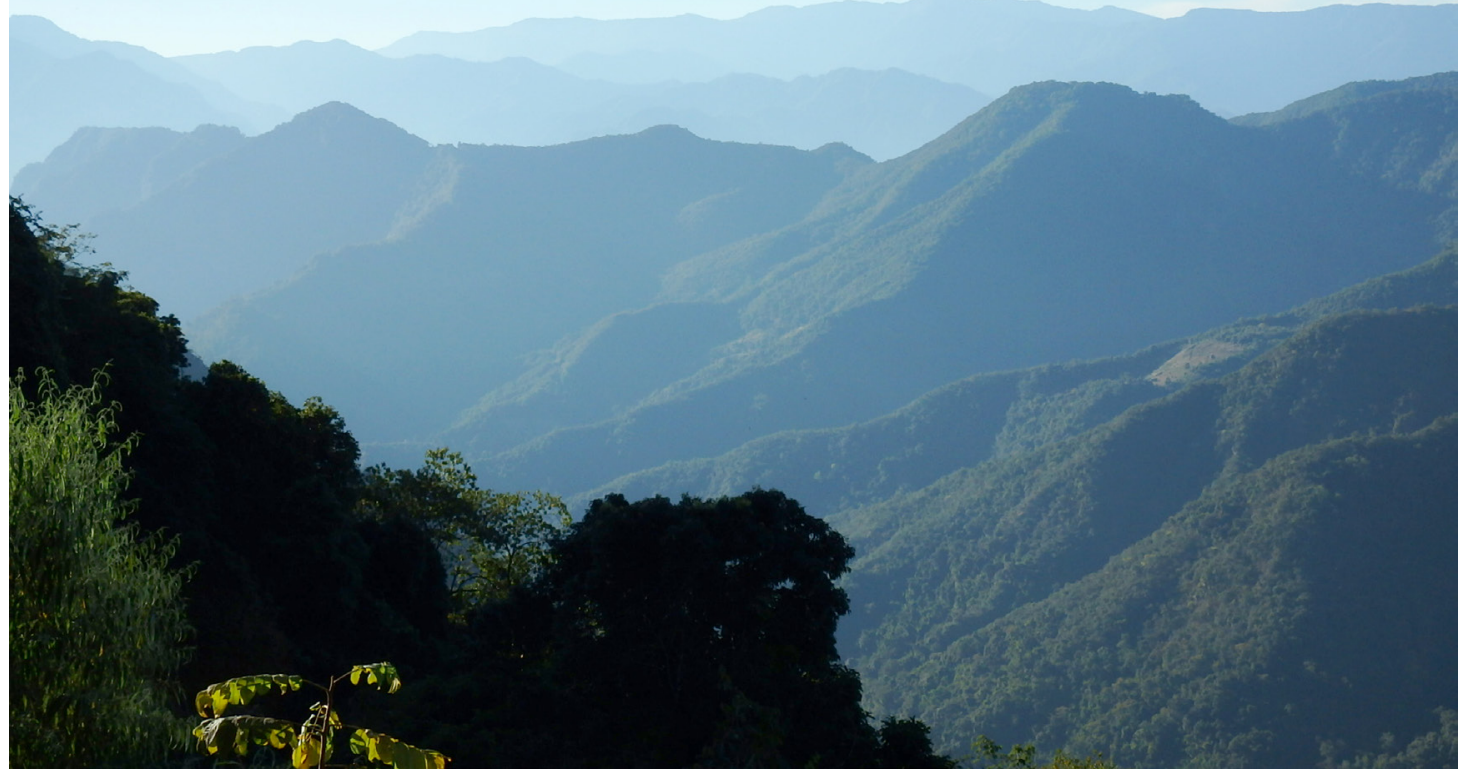

FIGURE 1. The mountains of southern Zhemgang are vast and difficult to explore.

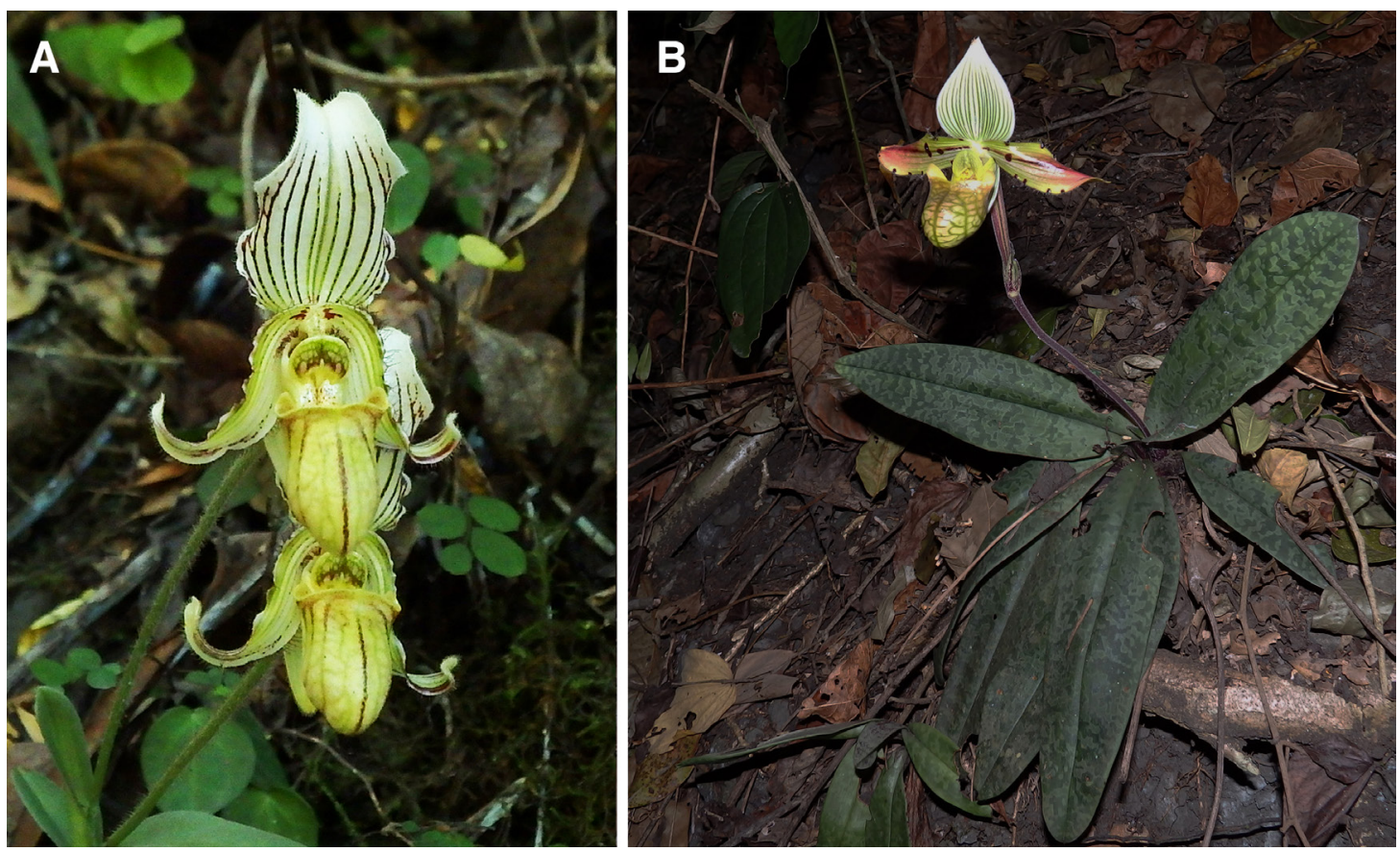

Figure 2. Species of Paphiopedilum at Ngangla-Kaktong region, Zhemgang, Bhutan. A, P. fairrieanum. B, P. venustum. LANKESTERIANA 17(3). 2017. (C) Universidad de Costa Rica, 2017. 


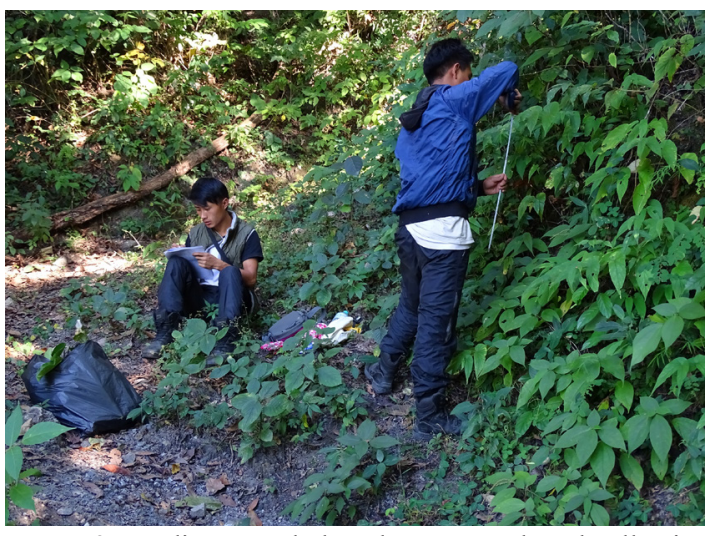

Figure 3. Tandin Wangchuk and Kezang Tobgyel collecting data at the type locality of Spathoglottis jetsunae.

limestone outcrops together with $P$. fairrieanum. At this site only a single Spathoglottis plant was seen; in a larger population of the Paphiopedilum. Additional studies are desirable to achieve a better understanding of the natural distribution, occurrence and threats to this newly discovered and hence, little known Spathoglottis.

Only Spathoglottis ixioides (D.Don) Lindl., a rather small and yellow-flowered species was previously listed for Bhutan (Pearce \& Cribb 2002). The discovery of the new and striking Spathoglottis is therefore a welcome contribution to the continuously increasing number of known orchid species documented for the small country known as the "Land of the Thunder Dragon".

\section{TAXONOMIC TREATMENT}

Spathoglottis jetsunae N.Gyeltshen, K.Tobgyel \& Dalström, sp. nov.

Type: Bhutan. Zhemgang, Ngangla Trong, terrestrial in shallow layers of soil on or below limestone outcrops, alt. 1038 m.a.s.1., 3 Nov. 2016, N. Gyeltshen, K. Tobgyel \& T. Wangchuk Ni.G-708-2016 (holotype: THIM). Fig. 4-6.

Diagnosis. Spathoglottis jetsuniae is similar to $S$. hardingiana C.S.P.Parish \& Rchb.f. (Fig.7), but differs by having sub-glabrous inflorescence, axis and pedicels, petals with abruptly acuminate apices curved forward, a yellow lip with a pair of spreading fleshy callus lobes and an additional, parallel pair of digitate, or "sausage-shaped", callus structures above, and a narrow and coiled-up, strap-like mid-lobe. In contrast,

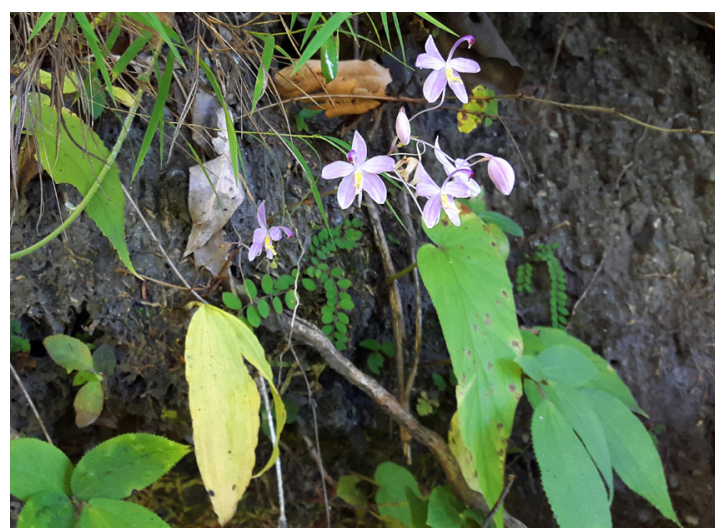

FIgURE 4. Natural habitat of Spathoglottis jetsunae in Zhemgang. Photo by Nima Gyeltshen.

S. hardingiana has distinctly pubescent inflorescence, axis, ovaries and pedicels, acute petals, a pale mauve lip with a single pair of thick and clavate, or bulbous, erect callus structures, and a porrect and narrowly triangular mid-lobe (Parish \& Reichenbach 1875; Curtis's Botanical Magazine 1904).

Terrestrial herb. Roots thin and fibrous, $c a$. 1-2 $\mathrm{mm}$ thick. Pseudobulbs globose-ovoid, ca. $2.5 \times$ $2.0 \mathrm{~cm}$, covered by fibrous sheaths. Leaves 1 to 3 , oblanceolate, narrowly acute to broadly acuminate, plicate, $c a .34 \times 4 \mathrm{~cm}$ long, proximately narrowed into a $c a .3 .5 \mathrm{~cm}$ long petiole-like base. Inflorescence axillary from the base of the pseudobulb, slender, erect to slightly arching, mainly glabrous turning micro-pubescent towards the apex; raceme manyflowered; peduncle slender with 5 tubular, acute ca. $1.5-3.5 \mathrm{~cm}$ long sheaths; rachis straight, $c a$. $13 \mathrm{~cm}$ long and rather dense-flowered; floral bracts narrowly acuminate, $4-10 \mathrm{~mm}$ long. Pedicel with ovary slender, glabrous, $4.0-5.5 \mathrm{~cm}$ long. Flowers ca. $2.5-2.8 \mathrm{~cm}$ across; dorsal sepal white turning bluish magenta with maturity, cuneate, elliptic and bluntly acute, ca. $14 \times 6 \mathrm{~mm}$; lateral sepals similar in color and shape, obtuse, $c a .13 .0-13.5 \times 6.0-6.5$ $\mathrm{mm}$; petals similar in color, cuneate, broadly elliptic, slightly oblique apically with an abruptly acuminate, ca. $2.3 \mathrm{~mm}$ long apex which is distinctly curved forward in the natural state, $c a .13 .5-14.0 \times 7.0$ $\mathrm{mm}$; lip flexibly attached at the base of the column, basally shallowly concave and indistinctly 3 -lobed; lateral lobes rounded, $c a$. 5.0-5.5 mm long, margins basally entire but increasingly pilose near the base 


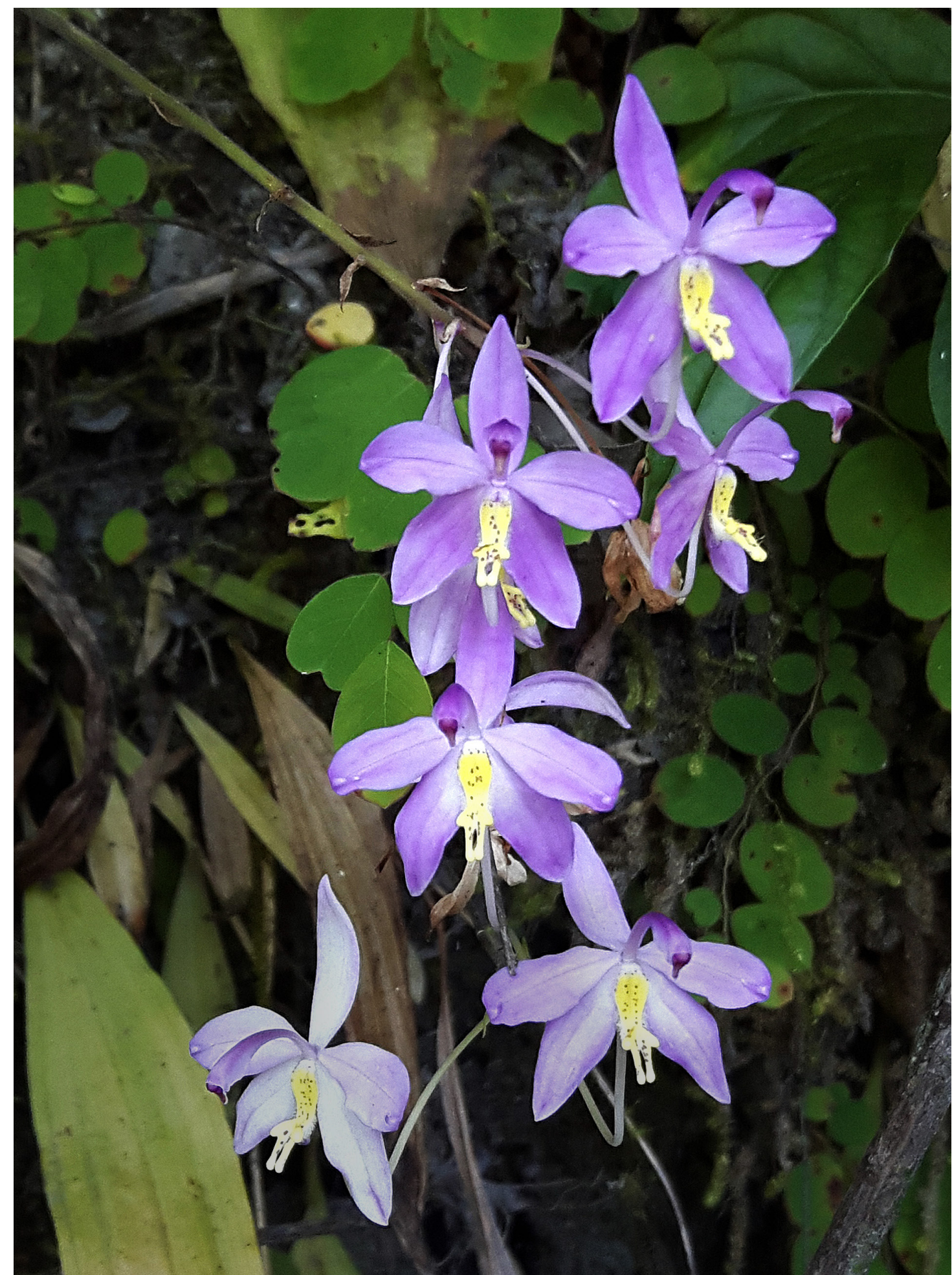

FIGURE 5. The striking flowers of Spathoglottis jetsunae. Photo by Nima Gyeltshen

LANKESTERIANA 17(3). 2017. (C) Universidad de Costa Rica, 2017. 

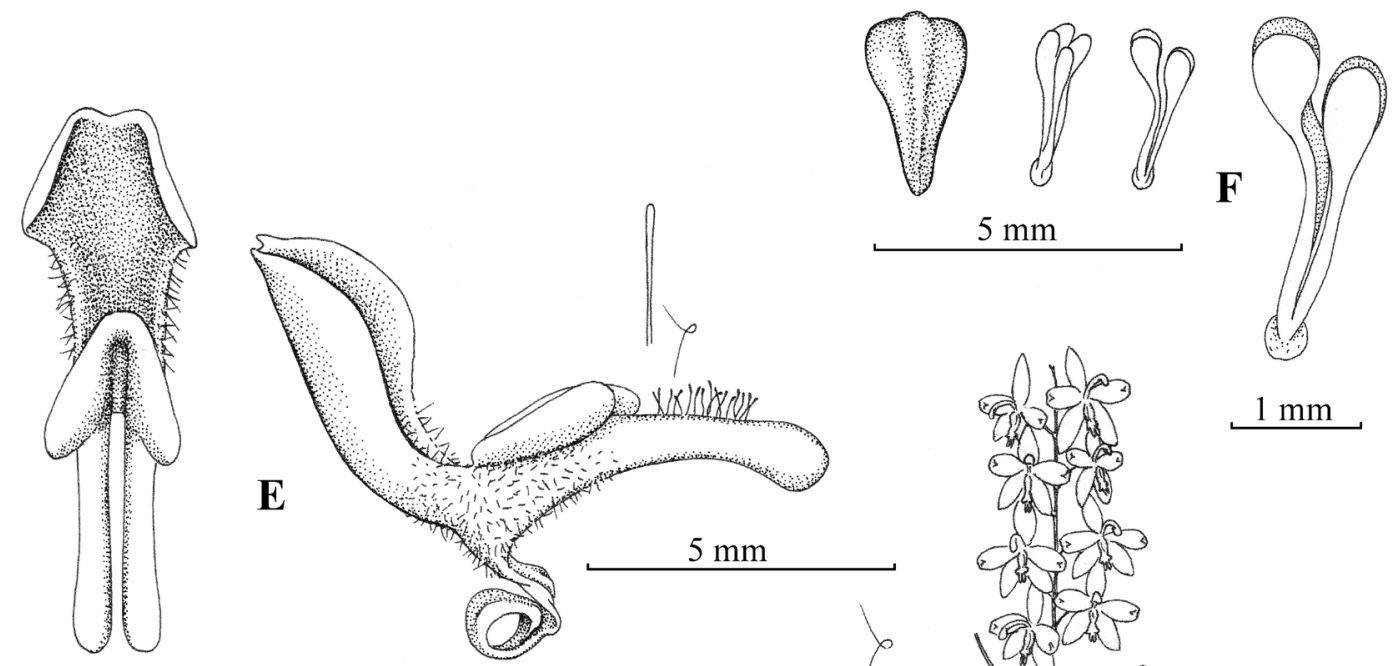

$\mathbf{E}$
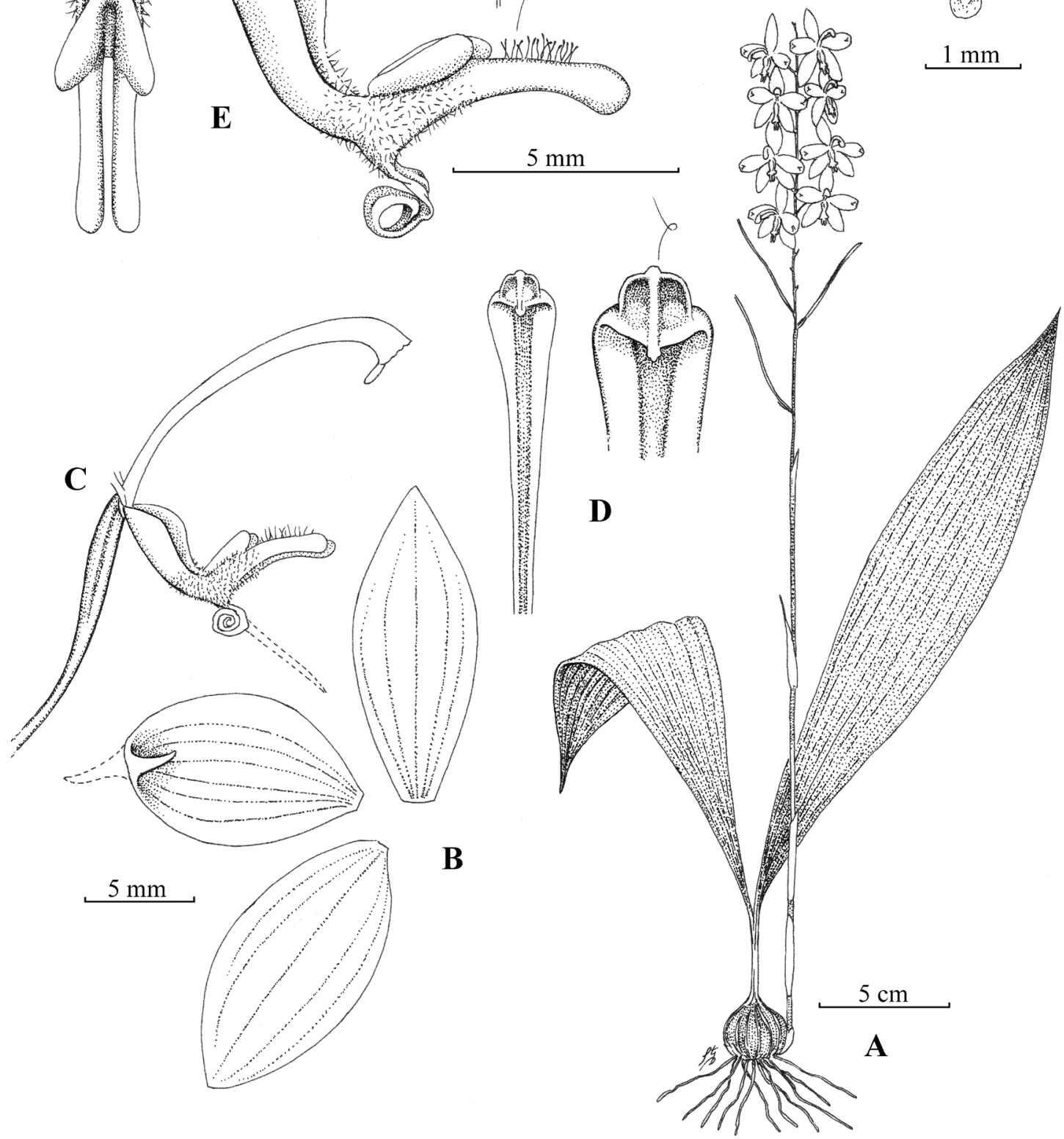

FIGURE 6. Spathoglottis jetsunae N.Gyeltshen, K.Tobgyel \& Dalström. A. Plant habit. B. Dissected flower without the lip. C. Lateral view of the lip and column. D. Ventral views of the column. E. Dorsal and lateral views of the lip. F. Dorsal view of the anther cap, and pollinaria. Drawn from the holotype by Stig Dalström. 


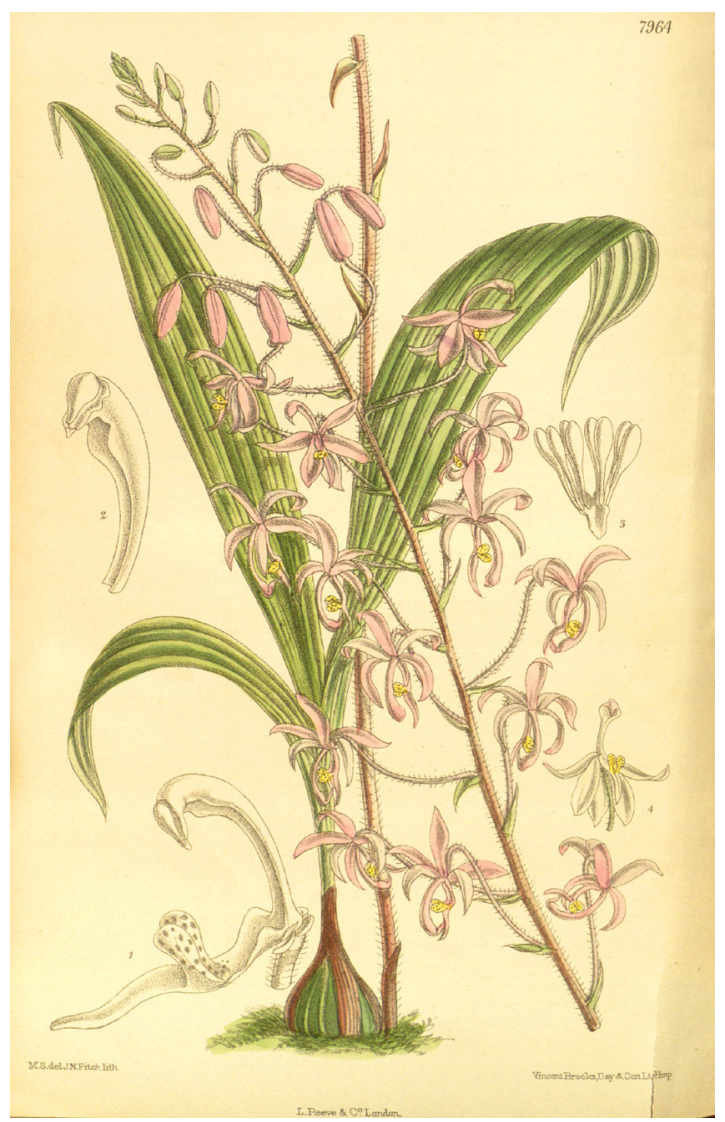

FIgURE 7. Spathoglottis hardingiana from the Curtis' Botanical Magazine, plate 7964 (1904).

of the callus, front-lobe reduced to a coiled-up, $c a$. $6 \mathrm{~mm}$ long narrow strap-like structure, callus of a pair of basally pubescent spreading fleshy lobes, with an additional erect and parallel pair of $c a$. 5.8-6.0 $\mathrm{mm}$ long digitate, or "sausage-shaped", structures; column slender, erect and gradually arcuate, narrowly winged throughout and becoming broader towards the apex, $c a .14 \mathrm{~mm}$ long; anther campanulate, pyriform in upper view, dorsally indistinctly lobulate; pollinarium of two sets of four elongate, clavate $c a$. 2.0-2.3 mm long pollinia. Capsule not seen.

Paratype: Bhutan, Zhemgang, Ngangla Trong, same area as the holotype, terrestrial on or below limestone outcroppings, alt. ca. 1038 m.a.s.1., 3 Nov. 2016, N. Gyeltshen, K. Tobgyel \& T. Wangchuk Ni.G-708 (THIM).

Other material StUdied: Samdrup Jongkhar,
Martshala and Sarjung, terrestrial in thin layer of soil on limestone outcrops, alt. 981 m.a.s.1., 8 Nov. 2016, N. Gyeltshen, K. Tobgyel \& T. Wangchuk s.n. (digital photographs in authors' archives).

Ecology: Spathoglottis jetsuniae grows terrestrially in shallow soil on or below NW facing limestone outcrops at approximately $980-1000$ m.a.s.l. elevation, with the soil $\mathrm{pH}$ of $7.1-7.8$, and in close proximity of Paphiopedilum fairrieanum populations. The forest vegetation in the selected plot is mostly dominated by evergreen trees including Rapanea capitellata (Wall.) Mez. (RBA $=28.99 \%$ ), Phoebe lanceolata (Nees.) Nees. $(\mathrm{RBA}=27.87 \%)$ and Acer oblongum Wall. ex DC. $(\mathrm{RBA}=18.11 \%)$, RBA of $P$. fairrieanum was $0.02 \%$ and $P$. venustum was $0.03 \%$. Total RBA of evergreen tree species in Ngangla and Kaktong habitats were $67.4 \%$ and 63.4 $\%$ respectively.

Distribution: Spathoglottis jetsuniae is so far only known from two localities in southeastern Bhutan.

EPONYMy: Spathoglottis jetsuniae is named in loving and respectful honor of Her Majesty the Queen Jetsun Pema Wangchuck of Bhutan, who has a dedicated and sincere interest in the protection of the environment and the wild flora and fauna of Bhutan.

AcknOwLEDGments. The authors would like to thank His Excellency Lyonpo Yeshey Dorji, the Minister of Agriculture and Forests for his constant encouragement. The authors would also like to thank Tashi Y. Dorji, Program Director of the NBC, for her constant guidance and motivation. We also thank Mrs. Sangay Dema (NBC), Dhan Bdr. Gurung (College of Natural Resources in Lobesa, Bhutan), Tandin Wangchuk (Former NBC contract staff), Choki Gyeltshen (NBC), and Dupchu Wangdi (NBC). We sincerely thank the Sarasota Orchid Society for continuous financial support and Wesley E. Higgins and the anonymous reviewers for improving the manuscript. Finally we thank Sharon and Russell Stephens of Sarasota, Florida, for contributing travel funds for the third author through grant \#20173198 from the Friends of Orchid Research Fund, administrated by the Community Foundation of Sarasota County.

\section{LITERATURE CITED}

Blume, C.L. (1825-1827). Bijdragen tot de flora van Nederlandsch Indië. Jakarta. 
Parish. C.S.P \& Reichenbach, H.G. (1875). Spathoglottis hardingiana, in H.G.Reichenbach, Otia Bot. Hamburg.: 45

Pearce, N.R. \& P.J. Cribb (2002). The Orchids of Bhutan. Royal Botanic Garden, 20A Inverleith Row, Edinburgh \& Royal Government of Bhutan.
Govaerts, R. (2017). World Checklist of Selected Plant Families: Royal Botanic Gardens, Kew. UK. http:// wcsp.science.kew.org. 
LANKESTERIANA 